\title{
The Dimensions of Communication in Teaching Grammar
}

\author{
Gentjana Panxhi \\ Lecturer at the Faculty of Education, "Aleksander Moisiu" Durres University UAMD \\ Email:genta_panxhi@yahoo.com
}

\author{
Aida Kurani \\ Lecturer at the Faculty of Education, "Aleksander Moisiu" Durres University UAMD \\ Email: kuraniaida@hotmail.com
}

Doi:10.5901/jesr.2014.v4n4p100

\begin{abstract}
Communicative language in teaching is not conceived simply as an object study, but as a communication tool and as a system of meaning. This one, as a practical activity that takes place in a social environment is closely related to communication. Teaching activities include attract attention or awareness of students' language forms in the context of meaningful communication. On the other side teaching methods based on different forms of communication ask for an increase more and more linguistic competence. Under this perspective, language is seen not only as a communication tool, but as the construction of thought. In this paper we intend to analyze communicative language teaching in general and grammar in particular, ways and methods that influence the selection of effective strategies in accordance with the context of language teaching. Since the purpose of the scholastic program is academic language acquisition for communicative purposes is clear that such a communicative grammar provides students with the tools that enable it to communicate through grammar in concrete situations. The question in the discussion currently is not whether teaching should focus on grammar, but how to teach grammar effectively for a successful communication.
\end{abstract}

Keywords: communication, language, grammar, teaching etc.

\section{Introduction}

The acquisition of language grammar is demanding more and more the growth of communicative competeces. In this paper we intend to generaly analyze communicative teaching of language and in particular grammar, ways and methods that influence the selection of effective strategies which are more appropriate to the context of language learning and communication.

Almost in all definitions of language, their common view is that the language is seen as a tool that serves to communicate. Sosyri (1966) the main representative of structuralism sees speaking as a skill, as a feature or a common trait of people to communicate. Within this complex he spotted the language as social component of speaking and speech as an individual and voluntary act. In his opinion the language is the link between thought and sound and is a tool where opinion is expressed through the sound. Opinions must be arranged properly and sound should be pronounced properly to implement the process of language. On his opinnion, laguage is the boundary between thought and sound, both of which combine to provide communication.

In compliance to Sosyrit, Harris (1987) argues that language is not seen as something marginal to understanding the world where we live, but as a central aspect of it where words are not just names or voice communication aids overlapped on the given row of items.

Bloomfield (1970) describes language as a set of signals which can be studied by linguist. He joins the opinion Saussure's that the linguist should study the language as it is spoken in the time of the study 'and form of language has a constant and determined meaning.

Chomsky defines language as a set of determined and indeterminate sentences, each determined in length and constructed from a given set of elements. Similar to the "language" and "speech" of Saussure's, Chomsky made a substantial difference between the knowledge of the rules of language from the individual which he defined as "competence" and the real use of language in real situations which he defined as "performance". According to him, linguists should study not only the performance but also communicative competence as the speakers use the power to go beyond the limits of any corps, being able to create and distinguish communicative competences as the ability to know 
when one should speak, when and why should not have spoken, with whom, when and in what ways.

Communicative competence is broader than linguistic competence, claims Stern, emphasizing that communicative competence means language competence, but the focus is intuitive domination of rules and social and cultural meanings forwarded by each sentence.

Harmer (2001) claims that from comunicative point of view of speaking includes two major categories: accuracy, which includes the correct use of vocabulary, grammar, pronunciation and fluency, which is considered to be the ability to continue when spontaneously speking. Knowledge of language and its use, are considered as two essential elements to effective communication (Bygate, 1987). While Anne Lazzarotto (2001) writes that oral communication is based on four dimensions or competencies: grammar competencies (phonology, vocabulary, word and sentence formation...); sociolinguistic competence (rules for interaction, social meanings); speech competence (cohesion and how sentences are related together); and strategic competence (additional strategies to be used in difficult strategies).

Language in communicative teaching is conceived not simply as an object of study, but as a communication tool and a system to express meanings. The fact that the language is used in daily life to share meaningful messages in concrete contexts of communication should be reflected in the auditorium.

The early 1970s, when communication methods appeared.

With appearance of this method the emphasis switched from learning the structure of language to the expression of its meaning. The support and its widespread use throughout the world has resulted in various discussions regarding the most effective approach to teaching language acquisition for communication purposes. Some have supported and continue to support teaching focused on linguistic form, others have rejected with the intention to focus on the communication of meaning.

This ongoing debate regarding the teaching and learning of grammar for communication purposes laid before all the recognition and implementation of appropriate methods efficiently.

The process of learning the language is a very complex process, where a role not only play an important teacher and his methods, but other factors, such as student with his individuality (his strategies styles of learning, his attitude toward school in general and in particular foreign language, his perceptions to teaching and learning of language and grammar), environment and culture of the learning.

Even in our country, Albania, with the entry of new technologies is felt the need for renewal of teaching language acquisition. Often teachers and students feel disappointed by the results they achieve in learning because they are not capable of apply grammatical knowledge gained during communication through spoken language.

Often students see grammar as difficult to acquire and as such, in some cases it becomes an obstacle to acquiring language. Many teachers, influenced by traditional ways of teaching and other factors, tent to give more importance to accuracy use of language, giving more exercises on grammar roles than is necessary, and do not promote the teaching and learning of language in function of communication. On the other hand, lies and lack of clear guidelines for teaching grammar in the curriculum and especially in problematic situations that teachers encounter in daily practice of language teaching.

In these conditions, and facing the challenge for teaching and acquisition of communicative function for an effective communication in Albanian language. If traditional teaching does not take into account the context of the communication, communicative teaching tryes to broader contemplate the grammatical competence, taking into consideration not only the recognition of rules and their use, but also the ability to select them according to communication situations.

Referring Newby-t, grammatical competence includes the following components:

1. The forms (morphology, syntax): how to create correct forms and structure of words and sentences (eg past forms of irregular verbs, interrogative sentences);

2. Meanings (semantics): what are the possible meanings to express our thoughts through grammatical forms in a given language (e.g. to refer to the future in English, there are available severeal meanings: prediction, planning, decision of the moment of talking, etc..); which should be used in a particular context.

3. Goal (pragmatic): how to use grammar to show intent or communication desire.

It is clear that such a communicative grammar provides students with tools that enable to communicate through grammar in concrete situations. As teaching is aimed at developing communicative competence, language acquisition is conceived as acquisition of linguistic tools to perform different functions. This conception of grammar and its acquisition has restructured the programe and methodology of language and grammar areas in education, teacher's and students' roles also the use of materials.

Language acquisition is consodered successful through activities that are based on the principles of communication, task and understanding:

- Activities that involve real communication promote learning. 
- Activities in which language is used to perform certain tasks promote meaningful learning.

- Understandable language helps the learning process. So, the activities are selected considering the principle of inclusion of students in the use of language and not practicing in mechanical ways structural models.

Replacement of mechanical exercises (for structures practice) with communication activities focused on the meaning is considered effective in developing communication skills. Using communicative activities such as role playing, interviews, simulations, linguistic games and other activities organized in a way to naturally include student groups in activities such as understanding the message, making queries to search for information, making questions to clarify doubts, keeping records, logically data streaming to share message, etc.

These activities, which activate students in communication through interaction and information sharing, enable them to develop interaction and communication skills and achieve communication goals on foreign language program. Functional communicative activities encourage students to engage in tasks (such as comparing several paintings showing similarities and their differences, finding information that is missing in the picture); social interaction activities encourage students to consider social context in communication (e.g. conversations, dialogues, game roles).

Personalization and creativity are important elements of communication that are encouraged to integrate in this methodology. In everyday life laguage is used as a communication tool to express thoughts, desires, needs, etc., of the speaker, but at the same time it is part of a creative process in which the speaker constantly create new discourses.

According to Richards and Rodgers does not have a text or a model that is accepted as universally authoritative. This is because, for some people, communicative teaching means integration of grammatical and functional aspects of language, and to other means the use of methodical procedures where students work in pairs or groups to solve problems using linguistic tools.

\section{Conclusions}

In the course of centuries the concept of grammar, teaching and learning have been and are closely related to theoretical and empirical developments in linguistics, psychology, sociology and education, as different in size and social factors, economic, ideological, technological, etc.

In recent decades, the wide acceptance of the communicative approach to language teaching, resulted in relatively different interpretations and applications.

In terms of today's global economy, free movement of people, requirements for the acquisition of language for communication purposes is growing.

A successful communication is closely related to grammatical accuracy, as grammatical ability is an important component of communicative ability. Teaching methods based on different forms of communication require an increasingly growth of linguistic competence. Under this perspective, language is seen not only as a communication tool, but also as the construction of thoughts.

\section{References}

Bloomfield , L. Le Langage, Paris, Payot, 1970.

Bourne, L., Dominowski, R., Loftus, E., \& Healy, A. (1986). Cognitive processes. Englewood Cliffs, Nj: Prentice-Hall.

Bygate, M. (1987). Speaking. Oxford: Oxford University Press

Chomsky, N. (1965). Aspects of the theory of syntax. Cambrige, MA: MIT Press.

Chomsky, N. (1968). Language and mind. New York: Harcourt Brace Jovanovich.

Chomsky, N. Syntactic Structures, The Hague/Paris: Mouton de Groyter (formerly Mouton the Hague) isa division of Walter de Greyter GmbH \& Co. KG. Berlin. Botimi i parë në 1957

Crystal, D. A First Dictionary of Linguistics and Phonetics, London: Andre Deutch Limited. 1987

Harmer, J. (2001). The Practice of English Language Teaching. Harlow: Pearson Education

Harris, Roy. Reading Saussure: A critical commentary on the Cours de linguistique générale. La Salle, Illinois: Open Court. 1987.ISBN 0-8126-9049-4

Hoti. I., (2011) Kompetencat komunikative në të mësuarit e gjuhës, Revista pedagogjike, ShB IZHA

Kaplan, E., \& Kaplan, G. (1971). The prelinguistique child. In J. Elliot (Ed.), Human development and cognitive processes. New York:Holt, Rinehart \& Winston.

Lazaraton, A. (2001). Teaching Oral Skills. In M. Celce-Murcia (Ed.), Teaching English as a second foreign language, Boston: Heinle and Heinle, f.103

Meunier.Jean\&Pierre, Peraya.Daniel, (2009) Hyrje në teoritë e komunikimit ShB Mirgeealb, QSSHE, Botim i dytë

Pearson, Eloise V., Ed Communication: Speaking and Listening ; A Communication Skills Curriculum and interdisciplinary Resourse Guide for Junior High Schools. Colorado Univ., Builder. Bureau of Communication Services and research ; Pub Date 72, 
document resume

Saussure, F. Course in General Linguistics, edited by Charles Bally, C. and Albert Sechehaye in collaboration with Albert Riedlinger.New York. McGraw-Hill Book Company, 1966 